\title{
Predictive Modelling of Mobile Marketing Usage among Generation Y: A Preliminary Survey
}

\author{
http://dx.doi.org/10.3991/ijim.v10i2.5545 \\ Mohammad Ismail, Razli Che Razak, Mohd Rafi Yaacob, \\ Mohd Nazri Zakaria, Nadia Hanum Amiruddin, Azyanee Luqman \\ Universiti Malaysia Kelantan, Malaysia.
}

\begin{abstract}
This preliminary analysis examines mobile marketing usage among Generation $Y$. This study investigates the level of mobile marketing usage among Gen $Y$ and to identify the relationships between attitude, subjective norm, perceived behavioural control, perceived risk, behavioural intention and actual usage. This study utilizes selfadministered survey questionnaires by using 115 students from University Malaysia Kelantan. Overall, the results provides verification of a positive relationship between the constructs of attitude, subjective norm, perceived behavioural control and perceived risk on intention to use mobile marketing services.
\end{abstract}

Index Terms-Mobile Marketing, Actual Usage, Behavioural Intention, Behaviour

\section{INTRODUCTION}

Nowadays, social networking has evolved into a completely new verbal advertising exchange tool at speedy as well as dynamic rates. An increasing number of businesses profiting from actual social networking along with other electronic digital devices in conducting their particular marketing endeavors, presents the prospect of studying more about the electronic-based marketing research [67]. Significantly, common technology enhancement such as the Smartphone or the mobile phone has turned it into international virus-like phenomena. Currently, mobile marketing is a widely used as fundamental tool by marketing experts to understand the relationship among consumers. The actual advancement of new technology for instance mobile technology seems to be critical in improving how consumers behave. It is able to offer consumers a better way to consider products, services, or companies and to help make a better connection between consumers and marketers [41]. According to [95], effective mobile marketing and advertising provides information and a better selection to purchasers to get products or services that can fulfill the requirements. In a study by [61] has demonstrated through user surveys that the mobile phone is the utmost widely-used device to access the Internet at about $74.3 \%$ usage. These statistical evidences on mobile marketing show that the usage and acceptance among users have increased in recent years.

Generation Y which is the "millennial generation", would be the main group connected to this technology, especially mobile usage in accessing the Internet, which has generally become an aspect of daily life. This group embraces technology applications in searching for prod- ucts and services, abandoning conventional buying actions of consumers [43]. Gen Y has been defined as "Millennials", "Echo Boomers", and individuals born approximately in between 1977-1994 [77]. In addition, the Gen Y has simply developed the status of getting exactly what they demand through technology. Gen Y consumers are well grounded and sensible for their age. This is because they were born into a technological and digital network society with worldwide borders becoming much clearer [48]. This generation is motivated by being able to access all types of information at their fingertips, quickly and easily [22]. The Generation Y routinely uses social websites for substantial socio-economic reputation, which resides in designed international locations where there may be somewhat unfettered access to information technology and social websites [19]. Hence, this particular study aims to analyze the Gen Y's attitude, subjective norms, perceived behavioural control, perceived risk, and intention in predicting the actual usage of mobile marketing services.Problem Statement

The mobile marketing is greatly perplexing and little is comprehended concerning its capacities or about the factors influencing the consumer's response and acceptance in using mobile marketing [18]. Expertise and researchers have incredible enthusiasm for comprehension the reasons why individuals acknowledge data innovation in order for them to create, access, and predict how users will respond to new technology [30]. Most of the studies only focus on explaining intentions and generally assume that they are good predictors of behavior [28]; there is still a lack of research in enlightenment the acknowledgment of mobile marketing and the understanding of usage behaviour [12],[83], [86].From the practical perspective, the dynamic expansion in the mobile industry has urged telecommunication operators in Malaysia to focus on mobile marketing services to concentrate on the young market that records for more than half of the business' endorser base [35].Companies have invested in developing these technologies but the usage level is still uncertain. [62] reveals in a survey report that only about $16.3 \%$ of mobile phone users access the internet via mobile phones; this implies a low rate of acceptance in Malaysia. These statistical evidences on mobile marketing show that the usage and acceptance among users remain unclear. According to [66], it costs up to tens of billions of dollars to build and develop the required infrastructure for mobile services in Malaysia. Therefore, it is important to ensure its maximum usage. It is essential for service providers to identify the 
PAPER

Predictive Modelling of Mobile Marketing Usage among Generation Y: A Preliminary Survey

factors or key drivers that influence consumers' acknowledgment of mobile marketing services. Considering the infancy stage of mobile marketing in Malaysia [91] and the usage level, which remains unknown, there is a crucial need to examine the acceptance of mobile marketing services. Previous studies on consumers' acceptance of mobile marketing services have mostly dealt with overseas situations (e.g.[15], [74], [75,] [83]) and only very limited studies exist in the context of Malaysia. The users' behaviour in mobile marketing services is likely to differ from one country to another. Culture plays a big role in affecting the consumers' affective and cognitive choice of consumption and spending [20]. Culture also has a strong impact on an individual's values and lifestyle [54]. Recently, there have been some studies on mobile services from oriental ethnic cultured countries such as Korea, Hong Kong, Taiwan, and China. However, these countries are racially homogeneous, i.e. the population comprises mainly of one race. Malaysia, on the other hand, comprising of people from different races such as Malays, Chinese, Indians, and other minority groups with diverse cultures and practices, provides a significantly different context of study in understanding consumers' acceptance of mobile marketing services. Moreover, prior studies of mobile marketing acceptance have only focused on the intention to use [15], [75], [83]. These studies are also relatively fragmented in terms of examined variables focusing only on mobile related activities and innovation attributes, rather than other aspects of end user perspectives such as perceived behavioural control, risk perception, and consumers' usage behavior. Focusing on the Gen $\mathrm{Y}$ group might help to bridge the gap given the lack of study about this group [50]. Gen Y includes the group of people who were born between 1977 to 1994 who are more divested in term of race and ethnic. They are also more segmented as an audience because of rapid expansion in cable TV channels, satellite, radio, and Internet. Influenced by speed of Internet, Gen Y group is less brand-loyal and flexible in changing fashion style.

\section{LITERATURE REVIEW}

\section{A. Theory of Planned Behaviour}

Theory Planned Behaviour is one of the theories that are widely used in technology acceptance studies. TPB [2] [4] is the extension of the theory of reasoned action [36] [7]. TPB is a basic theory and a good model in predicting various behaviours [71]. TPB is well researched and has been shown to predict behaviour across a variety of settings.As a general model, the TPB is designed to explain most human behaviours [4]. According to the Theory Planned Behaviour, an individual's behaviour can be clarified by his or her behavioural intention, which is mutually influenced by attitude, subjective norms, and perceived behavioural control. The adequacy of the TRA/TPB has gotten significant consideration. The proposition of a number of additional constructs might be helpfully added to the models. One of the compensation of the TRA/TPB is the miserly record that they give in the determinants of conduct. Thus, in addition to empirical verification the theoretical explanation of the role of other variables within the TPB is essential for the hypothetically intelligible model to give a superior result. The theoretical portrayal ought to determine the procedure by which the new variable impacts intentions and behavior, its relationship to existing parts of the TPB, and the scope of conditions over which such a variable may be relied upon to have an effect. As TPB is a basic model and subject to criticism, it is still open to inclusion of any variable that can increase the understanding of intention and behaviour. Since perceived risk has significantly influenced consumer's intention and behaviour [64], incorporating this construct into the model of mobile marketing acceptance is reasonably justified. The view of risk is critical crucial to numerous issues and issues including economy, administration, and public services fields [93]. In general the mobile service context, risk also assumes an imperative part in impacting shopper's conduct since mobile marketing services involve technologies, online transactions, Internet, downloading activities, and many more, which may comprise some important potential risks. Perceived risk has been claimed as a key element of the buyer seller relationship [33] [65] [85] [17]. The perceived risk theory was first introduced to explain the consumers' behaviour that is viewed as risktaking behaviour. As stated by [16], an early definition of perceived risk is a combination of uncertainty and seriousness of outcomes.

\section{B. Behavioural Intention (BI) and Actual Behaviour}

Behavioral intention can be explained as an implication of an individual's motivation to perform a given behaviour [68]. Intention has been claimed as the closest predictor of a behaviour [1]. Numerous studies have focused on behavioural intention or intention to use and defined BI in the exact study prospect. Generally, behavioural intention has been definite as "the strength of one's intention to perform a specified behaviour" [36]. The idea of behavioural intention was first found by [36] in the theory of reasoned action (TRA) which depicts that intentions are accepted to capture motivational componentsthat impact a behaviour and as well to determine the effort someone's willingnessto apply when performing a behaviour. Moreover, behavioural intention is an individual's subjective chances of performing a particular behaviour [2][7]. Based on the intention-based model, the TPB views that an fundamentally dictated by his/her behavioural intention, which is thusly anticipated by three conviction structures in particular state of attitude, subjective norm, and perceived behavioural control. Individual's conduct is fundamentally dictated by his/her behavioral goal, which is thusly anticipated by three conviction structures in particular state of mind, subjective standard, and saw behavioral control. The TPB model also suggests that intentions are the immediate antecedent of behaviour [3]. There is expansive proofin psychology [4] [8] that supports the component of intention as an analyst of behavior diagonally a extensive assortment of domains. Furthermore, in data system research, intention has been establish to be an indicator of innovation exploit [27] [86] [90]. Based on the TAM and TRA, behavioural intention is the most appropriate predictor for actual usage [7] [24]. The utilization of behavioural intention in foreseeing the actual behaviour recorded in numerous studies [27] [46] [51] [72] [58] [78][79][80].

\section{Actual use}

Even though numerous studies have verified the relationship between intention and actual usage, very limited studies have focused on actual behaviour or actual usage of the technology [45] [58]. Many studies only explain intentions and generally assume that they are good predictors of behaviour [28]. This study is distinct from previous 
PAPER

Predictive Modelling of Mobile Marketing Usage among Generation Y: A Preliminary Survey

limited studies in mobile marketing services, as it measures the users' self reported actual usage based on the number of usage in a week, average time per use, and frequency of use. This approach has been claimed as an accurate measure of actual usage [42] [94] and the selfreported measures used is the best relative indicator of usage behaviour [60]. Based on literature research, prior empirical studies of actual usage have been conducted in the areas of information technology (i.e. [9][27][25][90]) (e.g. [10][55][79][84]) (e.g. [44][67][94]), e-commerce (e.g. [70][71]), and instant messaging (e.g. [57]). There are various studies identified to mobile services however, not on actual usage (e.g [51][53][72][93]). Most of the studies focus on intention to use the technology, for example among mobile service subscribers in South Korea [80]. The outcomes disclose that behavioural intention has a crucial relationship with MMS usage behaviour.

\section{Attitude}

Attitude defines as an individual's positive or negative consideration regarding performing a specific behaviour. Attitude towards using technology is referred to the degree in which using technology is valued positively or negatively by an individual [24][27]. An individual who has more uplifting attitude towards a behaviour expected to develop the intention to perform that behaviour [4]. Attitude towards embracing a development is created by the individual's huge conviction about the outcomes of advancement (behavioural belief) and valuation of these consequences. Hence, attitude is obtained by the strength of the person's belief that adopting the innovation will lead to certain consequences [5]. The study by [63] proved that attitude has the highest contribution in developing intention to use mobile banking. The result of their study has proven that attitude significantly impact on intention to use mobile banking.

\section{E. Subjective norm}

Subjective norm defines characterizes to an individual's impression of other individuals' opinions on whether he or she should or should not perform a particular behaviour [4]. According to [81], subjective norm refers to an individual's perception of the social pressure to carry out certain behaviour. Subjective norm also defines to the perceived pressure from the general population who purchasers think are important to them. According to [90], subjective norm refers to the extent in which individuals perceive that important or significant others' that they ought to use an innovation. Subjective norm also involves the pressure felt by the person from another individual or a group in a society towards a certain behaviour [4]. Additionally, TPB has also suggested that subjective norm is become one of the influential factors of behavioural intention, which in turn will affect one to adopt a certain behaviour. This shows that subjective norm is the individual's belief, which is influenced by society and the surroundings. The belief that the environment can influence intention and behaviour [6] [1] reveals that subjective norm is a function of one's belief regarding social influence or a reference group. The belief based on subjective norm is also known as normative belief. This includes one's belief that an individual or a certain group that has been referred to agrees or does not agree in performing the behaviour. The perception has occurred due to the existence of this evaluation that can stimulate each of the individual to do or not to do a certain planned behaviour. The importance of subjective norm has also been highlighted by numerous studies, for example, the study by [38], which claims that subjective norm plays an important role in customers using mobile banking services.

\section{F. Perceived Behavioural Control}

Perceived Behavioural Control describes the extent in which his/her provides control in excess of personal or external factors that will facilitate or constrain this behavioural functionality [4]. Based on [8], perceived behavioural control identifies an individual's perception from the presence or lack of requisite resources, or opportunities important to perform behaviour. Perceived behavioural command describes users' perception of whether or not they have the essential resources such as time and money. Also, capability for example ability, information and selfefficacy within successfully executing the behavior. According to TPB, perceived behavioural control refers to the degree of control that is being observed by an individual on his/her skill or ability, resources and opportunity that he/she has to perform the behaviour [4][5][8]. Therefore, perceived behavioural control reflects the feel of ability or the individual capability to engage in certain behaviours [1]. The concept of PBC is most compatible with [14] the concept of self-efficacy, which usually individual's behaviours becoming firmly affected by simply their own self-confidence in their capacity to perform it. Perceived behavioural control in this study refers to the respondents' perception regarding accessing the opportunity needed towards using mobile marketing. It shows someone's opinion regarding simplicity, and utilization of to the inner (self-viability) and outside components that may execution performance of a behaviour (resources and technology facilitating condition). [88] recognizes encouraging conditions as those that reflect the accessibility of assets expected to participate in a conduct, for example, time, cash, or other particular assets. [73] verifies that perceived behavioural control significantly has positive effect on intention to adopt mobile services in China. Another study by [59] confirms that perceived behavioural control is positively related to the intention to use elearning.

\section{G. Perceived risk}

The concept of risk is essential to numerous issues or issues including economy, administration, and public services fields [94]. Particularly in the mobile service context, risk plays an imperative part in affecting consumer's behaviour on their purchases since mobile marketing services involve technologies, online transactions, Internet, downloading activities, and many more, which may comprise some important potential risks. Perceived risk has been claimed as a key element of the buyer seller relationship [33] [65] [85]. [17] First introduced perceived risk theory to explain consumers' behaviour that is viewed as risk-taking behaviour. As stated by [16], an early definition of perceived risk consists of two aspects, which are uncertainties and consequences. According to [85], the fundamental problem of consumer behaviour is the choice situation. Due to the result of a choice, which can only be known in the future, consumers, therefore, have to face the uncertainty of risk from that outcome. [85] then confirmed that perception of risk is a critical part of consumer behaviour. Many researchers have operationally defined uncertainty in terms of an individual's probabilistic belief [32]. In addition, [32] declares that the concept of per- 
ceived risk is one of the most persistent theories inhuman choices. The concept of risk has been defined differently according to disciplines, for example, in the disciplines of economics, psychology, statistical decision theory, and game theory, the concept of risk is associated with choice situations that involve potentially positive and negative outcomes. On the other hand, when studying perceived risk in consumer behaviour, the study mainly focuses on potentially negative outcomes [82]. [87] defined perceived risk as an assessment of uncertainties or lack of knowledge about the distribution of potential outcomes. The significant characteristic of perceived risk which distinguishes it from other disciplines such as behavioural decision theory, originates only from potentially negative outcomes [29] [82]. Generally, consumers anticipate a positive outcome, which may exceed their expectation from their purchase experience. However, if the purchasing transaction fails and they have negative consequences and experiences, then the purchase expectation cannot be accomplished [82]. Since the consumers are more likely to avoid negative outcomes instead of maximizing utility, the perceived risk theory provides powerful explanations related to consumers' behaviour in order to understand how consumers perceive risks and avoid negative outcomes when purchasing products or services [64]. In a study in the Malaysian context, [11] investigated the factors influencing the intention to use e-filling system among taxpayers. The study found that perceived risk (PR) is a significant determining factor of behavioural intention. As stated by [57], perceived risk is the most important determinant for consumer's adoption of mobile services in the mobile context.

\section{RESEARCH MODEL AND HyPOTHESES}

The research model integrates the variables of attitude, subjective norm, perceived behavioural control, perceived risk, behaviour intention, and actual use. The proposed construct and hypotheses are supported by prior studies from the literature review. Figure 1 illustrated the research model for this study. Based on this, the following hypotheses are proposed.

H1: Attitude will have a positive effect on intention to use mobile marketing services.

H2: Subjective norm will have positive effect on intention to use mobile marketing services.

H3: Perceived behavioural control will have positive effect on intention to use mobile marketing services.

H4: Perceived risk will have negative effect on intention to use mobile marketing services.

H5: Behavioural Intention will have positive effect on actual usage of mobile marketing services.

\section{Methodology}

Subjects of this research were individuals who used mobile marketing activities. Questionnaires were administered to undergraduate students from University Malaysia Kelantan. As this is an exploratory research, it used a convenience sample approach. A total of 200 questionnaires were distributed for the study. Incomplete questionnaires were discarded, leaving only 135 usable samples. The overall response rate for this study was67.5\%. The processing of data began after all of the required data had been gathered accordingly. Prior to the analysis, central editing was conducted to ensure only

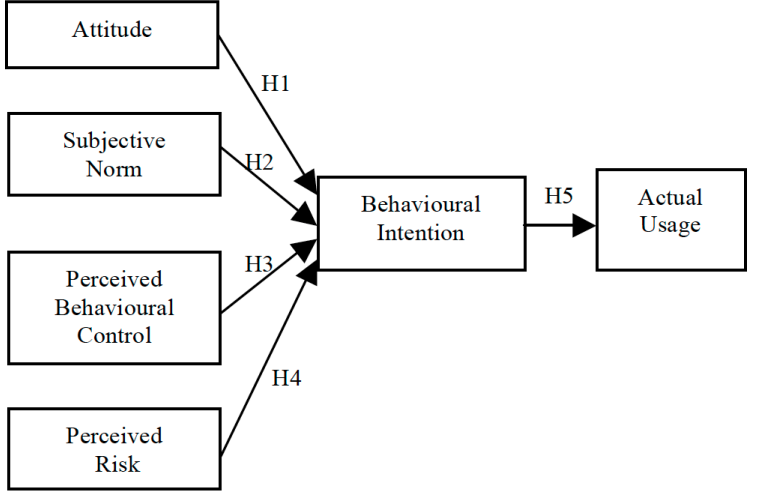

Figure 1. Research Framework

complete data were included. The dataset was coded and analysed using Statistical Package for Social Science (SPSS).

Six constructs were measured in this research: perceived risk, attitude, subjective norm, perceived behavioural control, behavioural intention, and actual use. The measurement items were adopted from different sources to suit the study. Items for perceived risk were adopted from [21] whereas perceived behavioural control from [79]. Meanwhile, items for actual usewere adopted from [24],[25], and [68]. On the other hand, the source of items for attitude, subjective norm, and behavioural intention were from [49] and [86]. All items were measured on a seven-point likert scale ranging from 1 (strongly disagree) to 7 (strongly agree).

\section{RESUlts AND FINDINGS}

Altogether, there were $22(16.3 \%)$ males and 113 $(83.7 \%)$ females involved in answering the distributed questionnaires. The target group of 21-22 years old shows the highest respondents with 60 of them (44.4\%) being 21 years old and the remaining $(48.9 \%)$ were 22 years old. In terms of ethnicity, the majorities are of the Malay ethnicity $(56.3 \%)$ followed by Chinese at $45(33.3 \%)$ and their highest completed education was the bachelor's degree at $132(99.3 \%)$ and $1(0.75 \%)$ at the diploma level. The highest mobile phone service provider used was Celcom at $48(35.6 \%)$ followed closely by Maxis at $45(33.3 \%)$, and Digi at $34(25.2 \%)$. Majority of the respondents used prepaid at $113(83.7 \%)$ and postpaid at $22(16.3 \%)$. In the mobile marketing services offered, $56.3 \%$ of the respondents used them compared to $46.7 \%$ who did not use the mobile marketing services.

Table II indicates the mean score, standard deviation, and variance of the study's composite variables. Since the measurement items used for these variables were the 7point likert scale, thus, the interpretation of mean score was categorized into low, moderate, and high. Subsequently, the mean score of 1 to 3.49 was treated as low, mean score of between 3.50 and 5.49 was treated as moderate, and the mean score between 5.50 and 7.00 indicated a high level. The results showed that the undergraduate student respondent sheld a neutral perception of mobile marketing usage. The item that achieved the highest mean score of 4.96 was behavioral intention, while the lowest mean score of 3.86 indicated actual use of mobile marketing. Based on the analysis, the standard deviation for all measurement instruments fell between the ranges of 0.92 and 0.18 , which reflect the existence of considerably ac- 
TABLE I.

BACKGROUND OF RESPONDENTS

\begin{tabular}{|c|c|c|c|}
\hline Background & Information & Frequency & Percentage(\%) \\
\hline Gender & $\begin{array}{c}\text { Male } \\
\text { Female }\end{array}$ & $\begin{array}{c}22 \\
113\end{array}$ & $\begin{array}{l}16.3 \\
83.7\end{array}$ \\
\hline Age & $\begin{array}{l}20 \\
21 \\
22 \\
23 \\
24\end{array}$ & $\begin{array}{c}7 \\
60 \\
66 \\
1 \\
1\end{array}$ & $\begin{array}{c}5.2 \\
33.3 \\
48.9 \\
0.7 \\
0.7\end{array}$ \\
\hline Ethnic & $\begin{array}{l}\text { Malay } \\
\text { Chinese } \\
\text { Indian } \\
\text { Others }\end{array}$ & $\begin{array}{c}76 \\
45 \\
7 \\
7\end{array}$ & $\begin{array}{c}56.3 \\
33.3 \\
5.2 \\
5.2\end{array}$ \\
\hline $\begin{array}{l}\text { Present Study } \\
\text { Programme }\end{array}$ & $\begin{array}{c}\text { Phd } \\
\text { Master Degree- } \\
\text { Bachelor Degree } \\
\text { Diploma }\end{array}$ & $\begin{array}{c}0 \\
0 \\
134 \\
1\end{array}$ & $\begin{array}{c}0.0 \\
0.0 \\
99.3 \\
0.7\end{array}$ \\
\hline $\begin{array}{l}\text { Mobile Phone } \\
\text { Service Provider }\end{array}$ & $\begin{array}{l}\text { Celcom } \\
\text { Digi } \\
\text { Maxis } \\
\text { U Mobile } \\
\text { Others }\end{array}$ & $\begin{array}{c}48 \\
34 \\
45 \\
6 \\
2 \\
\end{array}$ & $\begin{array}{c}35.6 \\
25.2 \\
33.3 \\
4.4 \\
1.5 \\
\end{array}$ \\
\hline $\begin{array}{l}\text { Types of phone } \\
\text { services }\end{array}$ & $\begin{array}{l}\text { Prepaid } \\
\text { Postpaid }\end{array}$ & $\begin{array}{c}113 \\
22\end{array}$ & $\begin{array}{l}83.7 \\
16.3\end{array}$ \\
\hline $\begin{array}{c}\text { Mobile Marketing } \\
\text { Service Used }\end{array}$ & $\begin{array}{l}\text { Yes } \\
\text { No }\end{array}$ & $\begin{array}{l}72 \\
63\end{array}$ & $\begin{array}{l}53.3 \\
46.7\end{array}$ \\
\hline
\end{tabular}

ceptable variability within the data set. The result demonstrated that the studied variables had different responses from the respondents, thus implying the existence of acceptable changes in responses.

As Table III shows, the composite reliability was estimated to evaluate the internal validity of the measurement model. In this study, the composite reliability of the constructs range from 0.89 to 0.97 . These were all greater than the benchmark of 0.70 as recommended by [39]. Furthermore, Cronbach's alpha was used to reconfirm the convergent validity of the model. As well as the composite reliability, Cronbach's alpha also uses the benchmark of 0.70 as its threshold. In all the constructs, the Cronbach's alpha exceeded the suggested value. These results ensure a proper ground for further analysis. The previous criteria tested show that the constructs and items were related to each other. There is another test on the convergent validity called the average variance extracted (AVE). The average variance extracted of all the constructs in the model ranging from 0.535 to 0.897 , indicate a good convergent validity of the model.

These research studies suggest assessing discriminant validity by investigating whether the AVE for the item is greater than its shared variance. This examines whether the square root of the AVE for a given construct is greater than the absolute value of the standardized correlation of the given construct with any other construct in the analysis. This procedure is shown in theTable IV, which [37] demonstrates that the discriminant validity of the model is established. Recommended stronger test of discriminant validity: the square root of the AVE for each construct should exceed the value of the standardized correlation with any other construct in the analysis. The logic here is that a latent construct should explain its item measures better than it explains another construct [39]. As illustrated in the table above, the square root of AVE is greater than the correlation with any other construct. Hence, the test of discriminant validity was also met.
TABLE II.

Mean, Standard DeViation, And VARIANCE VAlues Of The STUDY'S COMPOSITE VARIABLES

\begin{tabular}{|c|c|c|c|c|}
\hline \multirow[b]{2}{*}{ Variables } & \multicolumn{2}{|c|}{ Mean } & \multirow{2}{*}{$\begin{array}{l}\text { Standard } \\
\text { Deviation }\end{array}$} & \multirow[b]{2}{*}{ Variance } \\
\hline & Statistic & $\begin{array}{c}\text { Standard } \\
\text { Error }\end{array}$ & & \\
\hline $\begin{array}{l}\text { Perceived } \\
\text { Risk }\end{array}$ & 4.50 & 0.08 & 0.92 & 0.85 \\
\hline Attitude & 4.83 & 0.10 & 1.17 & 1.38 \\
\hline $\begin{array}{c}\text { Subjective } \\
\text { Norm }\end{array}$ & 4.26 & 0.09 & 1.00 & 0.99 \\
\hline $\begin{array}{c}\text { Perceived } \\
\text { Behavioural } \\
\text { Control }\end{array}$ & 4.76 & 0.09 & 1.04 & 1.08 \\
\hline $\begin{array}{c}\text { Behavioral } \\
\text { Intention }\end{array}$ & 4.96 & 0.10 & 1.12 & 1.25 \\
\hline Actual Use & 3.86 & 0.18 & 1.68 & 2.38 \\
\hline
\end{tabular}

\section{Aote: $\mathrm{N}=135$}

Measurement scale: 1 - Strongly Disagree to 7 - Strongly Agree

Measurement level: $1.00-3.49$, Low; $3.50-5.49$, Moderate; $5.50-7.00$, High

TABLE III.

RESUlt Of THE MEASUREMENT MODEL'S VALIDITY AND RELIABILITY

\begin{tabular}{|c|c|c|c|c|}
\hline Construct & Loadings & $a$ & CR & AVE \\
\hline \multicolumn{5}{|c|}{ Perceived Risk } \\
\hline PR1 & 0.691 & \multirow{7}{*}{0.863} & \multirow{7}{*}{0.888} & \multirow{7}{*}{0.535} \\
\hline PR2 & 0.601 & & & \\
\hline PR3 & 0.665 & & & \\
\hline PR4 & 0.777 & & & \\
\hline PR5 & 0.840 & & & \\
\hline PR6 & 0.685 & & & \\
\hline PR7 & 0.829 & & & \\
\hline \multicolumn{5}{|c|}{ Attitude } \\
\hline ATT1 & 0.890 & \multirow{5}{*}{0.958} & \multirow{5}{*}{0.968} & \multirow{5}{*}{0.857} \\
\hline ATT2 & 0.940 & & & \\
\hline ATT3 & 0.937 & & & \\
\hline ATT4 & 0.935 & & & \\
\hline ATT5 & 0.925 & & & \\
\hline \multicolumn{5}{|c|}{ Subjective Norm } \\
\hline SN1 & 0.855 & \multirow{5}{*}{0.922} & \multirow{5}{*}{0.941} & \multirow{5}{*}{0.763} \\
\hline SN2 & 0.848 & & & \\
\hline SN3 & 0.887 & & & \\
\hline SN4 & 0.891 & & & \\
\hline SN5 & 0.884 & & & \\
\hline \multicolumn{5}{|c|}{ Perceived Behavioural Control } \\
\hline PBC1 & 0.865 & \multirow{4}{*}{0.906} & \multirow{4}{*}{0.934} & \multirow{4}{*}{0.780} \\
\hline $\mathrm{PBC} 2$ & 0.878 & & & \\
\hline PBC3 & 0.897 & & & \\
\hline $\mathrm{PBC} 4$ & 0.893 & & & \\
\hline \multicolumn{5}{|c|}{ Behaviour Intention } \\
\hline BI 1 & 0.950 & \multirow{4}{*}{0.962} & \multirow{4}{*}{0.972} & \multirow{4}{*}{0.897} \\
\hline BI 2 & 0.947 & & & \\
\hline BI 3 & 0.955 & & & \\
\hline BI 4 & 0.936 & & & \\
\hline \multicolumn{5}{|c|}{ Actual Use } \\
\hline ACTUSE1 & 0.925 & \multirow{3}{*}{0.861} & \multirow{3}{*}{0.914} & \multirow{3}{*}{0.780} \\
\hline ACTUSE2 & 0.895 & & & \\
\hline ACTUSE3 & 0.827 & & & \\
\hline
\end{tabular}


TABLE IV.

DISCRIMINANT VALIDITY

\begin{tabular}{|l|c|c|c|c|c|c|}
\hline \multicolumn{1}{|c|}{ Variables } & $\mathbf{1}$ & $\mathbf{2}$ & $\mathbf{3}$ & $\mathbf{4}$ & $\mathbf{5}$ & $\mathbf{6}$ \\
\hline RP & 0.731 & & & & & \\
\hline ATT & -0.281 & 0.925 & & & & \\
\hline SN & -0.169 & 0.539 & 0.873 & & & \\
\hline PBC & -0.115 & 0.630 & 0.538 & 0.883 & & \\
\hline BI & -0.284 & 0.669 & 0.546 & 0.741 & 0.947 & \\
\hline ACTUSE & -0.100 & 0.152 & 0.138 & 0.084 & 0.230 & 0.883 \\
\hline
\end{tabular}

TABLE V.

SUMMARY OF THE STRUCTURAL MODEL ANALYSIS

\begin{tabular}{|c|l|c|c|c|}
\hline & \multicolumn{1}{|c|}{ Relationship } & $\begin{array}{c}\text { Path Coeffi- } \\
\text { cient }\end{array}$ & T-Value & Supported \\
\hline H1 & PR $>$ BI & -0.136 & $2.126^{*}$ & Yes \\
\hline H2 & ATT $>$ BI & 0.251 & $2.641^{* *}$ & Yes \\
\hline H3 & SN $>$ BI & 0.115 & $1.718^{*}$ & Yes \\
\hline H4 & PBC $>$ BI & 0.506 & $5.759^{* *}$ & Yes \\
\hline H5 & BI $>$ ACTUSE & 0.230 & $3.149^{* *}$ & Yes \\
\hline
\end{tabular}

The result in Table $\mathrm{V}$ indicates that $\mathrm{PR}$ is negatively and significantly associated with $\mathrm{BI}(\mathrm{t}=2.126, \mathrm{p}<0.05)$. Apart from that, the study also found that there are positive and significant relationships between ATT $(\mathrm{t}=2.641$, $\mathrm{p}<0.01)$, SN $(\mathrm{t}=1.718, \mathrm{p}<0.05), \operatorname{PBC}(\mathrm{t}=5.759, \mathrm{p}<0.01)$, and BI. Thus, these results support $\mathrm{H} 1-\mathrm{H} 4$. The $\mathrm{R}^{2}$ of Behavioral Intention was 0.644 , which indicates that the factors variables explain $64.4 \%$ of the variance of mobile marketing services intention by the respondents.

Finally, BI was found to be positively and significantly associated with ACTUSE $(\mathrm{t}=3.149, \mathrm{p}<0.01)$. Hence, H5 is supported. Result also shows that the extent of intention to mobile marketing services was positively related to the actual use of mobile marketing services. The $\mathrm{R}^{2}$ was 0.053 , which indicates that the behavioral intention to mobile marketing services is only explain $5.3 \%$ of the variance of the actual use.

\section{Discussion AND CONCLUSION}

This study has verified the force of the Theory of Planned Behavior for research in the area of mobile marketing among the Gen Y. The research data provides verification of a positive relationship between the constructs of attitude, subjective norm, perceived behavioral control, and perceived risk on intention to use mobile marketing services. Additionally, the frequently mentioned needs pertaining to mobile marketing demonstrate several benefits that continue to be empirically endorsed with this study. Prior studies have found that the TPB has been applied in explaining behavioural intention. The proposed model has been empirically tested using data collected obtained from a survey by distributing questionnaires on mobile marketing services.

The structural equation modeling technique was used to evaluate the variables to examine the reliability and validity of the measurement variables. The findings of this study strongly suggest that only four variables have a higher capability to predict and enlighten the behavioural intention of consumers to use mobile marketing services. The result of this paper provides necessary reference to promote mobile marketing services in practice. Based on the result of this study, mobile marketing services could impact usage among the Gen Y.

There are numerous conceivable focuses, which can be enhanced regarding mobile marketing, but what we are looking for is to provide more and more complete services and fulfill their prerequisites. It is imperative to focus on the Gen Y when using an online shopping environment in which there are a large number of different performers. In spite of the fact that this paper has achieved certain accomplishments, it additionally confronts numerous limitations. Firstly, as a result of time period limit, we only obtained a small amount of questionnaires. Thus, there is a shortcoming in the sample amount comprising only of University Malaysia Kelantan students more samples should be included in the follow-up research. Secondly, this paper researched mobile marketing services, and as such, it should be sensible and focus on applying the research results to specific mobile businesses. Thirdly, since this paper looked into versatile promoting administrations, it ought to be judicious and centered to apply the actual evaluation outcomes to a specific portable commerce In the follow-up research, we can enhance the models for further research.

\section{REFERENCES}

[1] Ajzen, I.( 2005), "Attitudes, personality and behavior (Second edition)". New York, USA: Open University Press.

[2] Ajzen, I. (1985), " From intentions to actions: A theory of planned behavior". In J. K. (Eds.), \& J. Beckman, Action-control: From Cognition to Behavior. Heidelberg: Springer, pp. 11-39. http://dx.doi.org/10.1007/978-3-642-69746-3 2

[3] Ajzen, I. (2002), "Perceived behavorial control, self-efficacy, locus of control, and the theory of planned behavior". Journal of Applied Social Psychology, Vol. 32 No.4, pp. 665-683. http://dx.doi.org/10.1111/j.1559-1816.2002.tb00236.x

[4] Ajzen, I. (1991),"The theory of planned behaviour. Organizational behavior and human decision processes", Vol 50, pp. 179-211. http://dx.doi.org/10.1016/0749-5978(91)90020-T

[5] Ajzen, I., \& Driver, B. E. (1992), "Prediction of leisure participation from behavioral, motive and control beliefs: An application of the theory of planned behavior". Leisure Sciences, Vol.13 No.3, pp. 185-204. http://dx.doi.org/10.1080/01490409109513137

[6] Ajzen, I., \&Fishbein, M. (1970), "The prediction of behavior from attitudinal and normative variables". Journal of Experimental Social Psychology, Vol. 6 No. 4, 466-487. http://dx.doi.org/10.1016/0022-1031(70)90057-0

[7] Ajzen, I., \&Fishbein, M. (1980), "Understanding attitude and predicting social behavior". Englewoods Cliffs, NJ: Prentice-Hall Inc.

[8] Ajzen, I., \& Madden, T. J. (1986), " Prediction of goal-directed behavior: attitudes, intentions, and perceived behavioral control". Journal Of Experimental Social Psychology, pp.453-474. http://dx.doi.org/10.1016/0022-1031(86)90045-4

[9] Al-Gahtani, S. S., \& King, M. (1999), "Attitudes, satisfaction and usage: factors contributing to each in the acceptance of information technology" Behavior and Information Technology, Vol. 18 No. 4, pp.277-297. http://dx.doi.org/10.1080/01449299 $\underline{9119020}$

[10] Al-Majali, M., \& Nik Kamariah, N. M. (2010), "Application of decomposed theory of planned behavior on internet banking adoption in Jordan". Journal of Internet Banking and Commerce, Vol. 15 No. 2, pp. 1-7.

[11] Anna, C. A., \& Bee, N. L. (2010), "The acceptance of the e-filing system by malaysian taxpayers: A simplified model". Electronic Journal of e-Government, Vol. 8 No. 1, pp.13-22.

[12] Balasubramanian, S., Peterson, R. A., \&Jarvenpaa, S. L. (2002), " Exploring the implications of $\mathrm{m}$-commerce for markets and marketing".Journal of academy of Marketing Science, Vol. 30 No. 4, pp.348-361. http://dx.doi.org/10.1177/009207002236910 
[13] Bandura, A. (1995), "Self-Efficacy in changing society". New York: Cambridge University Press. http://dx.doi.org/10.1017/ CBO9780511527692

[14] Bandura, A. (1991)," Social cognitive theory of self-regulation". Organizational Behavior and Human Decision Processes, Vol 50, pp. 248-287. http://dx.doi.org/10.1016/0749-5978(91)90022-L

[15] Bauer, H. H., Barnes, S. J., Reichardt, T., \& Neumann, M. M. (2005), "Driving consumer acceptance of mobile marketing: A theoretical framework and empirical study".Journal of Electronic Commerce Research, Vol 6 No. 3, pp. 181-192.

[16] Bauer, R. A. (1967), "Consumer behavior as risk taking". In D. F. Cox, Risk taking and information handling in consumer behavior,.Boston,MA: Graduate School of Business Administration, Harvard University, pp. 23-33.

[17] Bauer, R. A. (1960), "Consumer behavior as risk taking, in R.S". Hancock (ed), Dynamic Marketing for a Changing World. Proceedings of the 43rd National Conference of the American Marketing Association, pp. 389-398.

[18] Becker, M. (2006), "Mobile ecosystem \& strategic alliancespractice, elements, and framework". Retrieved from http://iloopmobile.com

[19] Boltom, R. N. (2013), "Understanding generation Y and theiruse of social media: A review and research agenda". Loughborough University Institutional Repository.

[20] Briley, D. A., \& Williams, J. D. (1998), "Emotive and cognitive effects of culture".Asia PacificAdvances in Consumer Research, Vol 3, 26-29.

[21] Chen, L. D. (2008), "A model of consumer acceptance of mobile payment." International JournalMobile Communications, Vol.6 No.1, pp. 32-52. http://dx.doi.org/10.1504/IJMC.2008.015997

[22] C. Williams.,\& Robert, A. P. (2010), "Marketing to the generations". Journal of Behavioral Studies in Business.

[23] Davis, F. D. (1986), "A technology acceptance model for empirically testing new end-user information systems. Theory and results". Doctoral dissertation, Sloan School of Management, Massachusetts Institute of Technology.

[24] Davis, F. D. (1989), " Perceived usefulness, perceived ease of use, and user acceptance of information technology". MIS Quarterly, Vol. 13 No.3, pp. 319-340. http://dx.doi.org/10.2307/249008

[25] Davis, F. D. (1993), "User Acceptance of Information Technology: System Characteristics, User Perceptions and Behavioral Impacts". International Journal Man- Machines Studies, Vol. 38, pp.475-487. http://dx.doi.org/10.1006/imms.1993.1022

[26] Davis, F. D., Bagozzi, R. P., \&Warshaw, P. R. (1992), "Extrinsic and Intrinsic Motivation to use computers in the workplace". Journal of Applied Psychology, Vol. 22No.14, pp. 1111-1132.

[27] Davis, F. D., Bagozzi, R. P., \&Warshaw, P. R. (1989), "User acceptance of computer technology: A comparison of two theoretical models". Management Science, pp.982- 1003. http://dx.doi.org/10.1287/mnsc.35.8.982

[28] De Canniere, M. H., De Pelsmacker, P., \&Geuens, M. (2009), "Relationship quality and the theory of planned behavior models of behavioral intentions and purchase behavior". Journal of Business Research, Vol. 62, pp. 82-92. http://dx.doi.org/10.1016/ j.jbusres.2008.01.001

[29] Dholakia, U. M. (2001), "A motivational process model of product involvement and consumer risk perception". European Journal of Marketing, Vol. 35No.11/12, pp. 1340-1362. http://dx.doi.org/10.1108/EUM0000000006479

[30] Dillon, A., \& Morris, M. G. (1996), "User acceptance of new information technology: theories and models". Annual Review of Information Science and Technology, Vol. 31, pp.3-32.

[31] Ding, L., Velicer, W. F., \& Harlow, L. L. (1995), "Effects of estimation methods, number of indicators per factor, and improper solutions on structural equation modeling fit indices". Structural Equation Modeling, Vol. 2 No.2, pp. 119-143. http://dx.doi.org/10.1080/10705519509540000

[32] Dowling, G. R. (1986), "Perceived risk: the concept and its measurement". Psychology \& Marketing, Vol. 3, pp. 193-210. http://dx.doi.org/10.1002/mar.4220030307

[33] Dowling, G. R., \&Staelin, R. (1994), " A model of perceived risk and intended risk-handling activity". Journal of Consumer Research, Vol. 21, pp. 119-134. http://dx.doi.org/10.1086/209386
[34] Eagly\&Chaiken, (1993), "The psychology of attitudes". Fort Worth, TX: Harcourt, Brace, \&Janovich, pp. 794.

[35] Eu, G. T.(2009). "Hello, young phone users". New Straits Times.

[36] Fishbein, M., \&Ajzen, I. (1975)."Belief, attitude, intention, behavior:An introduction to theory and research". Addison-Wesley.

[37] Fornell C \&Larcker DF. (1981), "Structural equation models with unobservable variables and measurement error". Journal of Marketing Research. Vol. 18 No.3, pp. 39-50. http://dx.doi.org/10.2307/3151312

[38] Gilaninia, S., Delafrooz, N. \&Machiani, A. R. N. (2012), "Identifying effective factors on consumer intention to use mobile banking services", Journal of Basic and Applied Scientific Research, Vol. 2 No.11, pp.11014- 11020.

[39] Hair, J. F., Black, W. C., Babin, B. J., \& Anderson, R. E. (2010), "Multivariate data analysis (7th ed)". New Jersey: Pearson Prentice Hall.

[40] Hair JF, Black B, Babin B, AndersonRE\& Tatham RL. ( 2006), "Multivariate Data Analysis".

[41] Hamisah Haji Hassan \&SamsudinA.Rahim. (2008), "Factors affecting online purchasing behavior".Malaysian Journal of Communication, Vol. 2, pp. 1-19.

[42] Hartley, C., Brecht, M., Pagery, P., Weeks, G., Chapanis, A., \&Hoecker, D. (1977), "Subjective time estimates of work tasks by office workers". Journal Occupational Psychology, Vol. 50,pp. 23-36. http://dx.doi.org/10.1111/j.2044-8325.1977.tb00355.x

[43] Harvi Muhammad Lutfi. (2014), "Study of generation Y attitude towards usage of internet for e-commerce in Msc Landmark, Kuala Lumpur \&SelangorState". Thesis Othman Yeop Abdullah Graduates School Of Business. University Utara Malaysia.

[44] Heijden, H. V., Verhagen, T., \&Creemers, M. (2003), "Understanding online purchase intentions: Contributions from technology and trust perspectives". European Journal of Information Systems, Vol. 12 No.1, pp.41-48. http://dx.doi.org/10.1057/ palgrave.ejis.3000445

[45] Jayasingh, S., \&Eze, U. C. (2009), " An empirical analysis of consumer behavioral intention toward mobile coupons in malaysia".International Journal of Business and Information, Vol. 4 No. 2, pp.221-242.

[46] Karjaluoto, H., \&Alatalo, T. (2007), "Consumers' attitudes towards and intention to participate in mobile marketing". International Journal Service Technology and Management, Vol. 8No. 2/3, pp. 155-173. http://dx.doi.org/10.1504/IJSTM.2007.012866

[47] Kaylene, Karjaluoto, H., \&Alatalo, T. (2007), "Consumers' attitudes towards and intention to participate in mobile marketing". International Journal Service Technology and Management, Vol.8 No. 2/3, pp.155-173. http://dx.doi.org/10.1504/IJSTM.2007. $\underline{012866}$

[48] Kelloway, E. K. (1998), "Using Lisrel for structural equation modelling". CA: International Educational and Professional Publisher: SAGE Publications.

[49] Khalil, M. N., \& Pearson, J. M. (2008), "An exploratory study into the adoption of internet banking in a developing country: Malaysia". Journal of Internet Commerce, Vol. 7 No.1,pp. 29-73. http://dx.doi.org/10.1080/15332860802004162

[50] Kim-Choy Chung, David K. Holdsworth, (2012), "Culture and behavioural intent to adopt mobile commerce among the Y Generation: comparative analyses between Kazakhstan, Morocco and Singapore", Young Consumers, Vol. 13 Iss: 3, pp.224 - 241 http://dx.doi.org/10.1108/17473611211261629

[51] Koivumaki, T., Ristolo, a., \&Kesti, M. (2006), "Predicting consumer acceptance in mobile services: Empirical evidence from an experimental end user environment". International Journal Mobile Communications, Vol. 4 No. 4, pp.418-435. http://dx.doi.org/10.1504/IJMC.2006.008950

[52] Krecjie And Morgan (1970), "Educational and psychological measurement 1970".University Of Minnesota, Duluth Daryle W. Morgan Texas A. \& M. University, Vol. 30, pp. 607-610.

[53] Kwon, H. S., \& Chidambaram, L. (2000), "A test of the technology acceptance model. The case of cellular telephone adoption." Proceedings of the 33rd Hawaii International.

[54] Lai, F. S., Chong, S. C., Sia, B. K., \&Ooi, B. C. (2010)," Culture and consumer behaviour: comparisons between Malays and chi- 
nese in Malaysia". International Journal ofInnovation, Management and Technology, Vol. 1 No. 2, pp.180-185.

[55] Lau, A. S. (2002), " Strategies to Motivate Brokers Adopting Online Trading in Hong Kong Financial Market". Review of Pacific Basin Financial Markets and Policies, Vol. 5 No. 4,pp. 471- 489. http://dx.doi.org/10.1142/S0219091502000894

[56] Legris, P., Ingham, J., \&Collerette, P. (2003), " Why do people use information technology? A critical review of the technology acceptance model". Information \& Management, Vol. 40, pp. 191204. http://dx.doi.org/10.1016/S0378-7206(01)00143-4

[57] Li, Z., \& Bai, X. (2010), " Influences of perceived risk and system usability on the adoption of mobile banking service". Proceedings of the Third International Symposium on Computer Science and Computational Technology (ISCSCT '10), Jiaozuo, China,pp. 5154.

[58] Lu, Y., Zhou, T., \& Wang, B. (2009),"Exploring Chinese users' acceptance of instant messaging using the theory of planned behavior, the technology acceptance model, and the flow theory". Computers in Human Behavior, Vol. 25, pp.29-39. http://dx.doi.org/10.1016/j.chb.2008.06.002

[59] Lee, M.-C. (2010), "Explaining and predicting users' continuance intention toward e-learning: An extension of the expectationconfirmation model". Computers \&Education, Vol. 54, pp. 506516. http://dx.doi.org/10.1016/j.compedu.2009.09.002

[60] Legris, P., Ingham, J., \&Collerette, P. (2003)," Why do people use information technology? A critical review of the technology acceptance model". Information \& Management, Vol. 40, pp. 191204. http://dx.doi.org/10.1016/S0378-7206(01)00143-4

[61] Malaysia Communication And Multimedia Commission. (2014)."Hand Phone Users Survey 2014".

[62] Malaysia Communication And Multimedia Commission. (2009), "Communication and multimedia selected facts and figures". Retrieved from http://www.skmm.gov.my

[63] Mian, T. S and Rizwan, M. (2013), "Determinants of customer intention to use mobile banking: An empirical research based on Extended Technology Acceptance Model". Journal of Basic and Applied Scientific Research, Vol. 3 No. 11, pp.201-211.

[64] Mitchell,V.-W.(1999),"Consumer perceived risk: Conceptualizations and models. European Journal of Marketing, Vol. 33 No. 1/2, pp. 163-195. http://dx.doi.org/10.1108/03090569910249229

[65] Mitchell, V.-W. (1992), "Understanding consumers' behavior. Can perceived risk theory help". Management Decision, Vol. 30 No. 2, pp. 26-31.

[66] Muthaiyah, S. (2004), "Key success factors of 3rd generation mobile network services for M- Commerce in Malaysia". American Journal of App

[67] MohdIrwanDahnil, KamarulMizalMarzuki, Juliana Langgat, \&NoorFzlindaFabeil. (2014), "Factors influencing SME's adoption of social media marketing". Procedia Social and Behavioral Sciences, Vol. 148, pp. 119 - 126. http://dx.doi.org/10.1016/ j.sbspro.2014.07.025

[68] Moon, J. \& Kim, Y. (2001), " Extending the TAM for a WorldWide-Web context".Information and Management, Vol. 38, pp. 217-230. http://dx.doi.org/10.1016/S0378-7206(00)00061-6

[69] Niaura, A. (2013), "Using the theory of planned behavior to investigate the determinants of environmental behavior among youth". Environmental Research, Engineering and Management, Vol. 1 No. 63, pp. 74-81. http://dx.doi.org/10.5755/j01. erem.63.1.2901

[70] Norazah, M. S., Ramayah, T., \&Norbayah, M. S. (2008), "Internet shopping acceptance. Examining the influence of intrinsic versus extrinsic motivations". Direct Marketing: AnInternational, Vol. 2 No.2, pp. 97-110. http://dx.doi.org/10.1108/17505930810881752

[71] Pavlou, P. A., \&Fygenson, M. (2006), "Understanding and predicting electronic commerce adoption: An extension of the theory of planned behavior". MIS Quarterly, Vol. 30No. 1, pp.115-143.

[72] Pedersen, P. E. (2005), "Adoption of mobile internet services: an exploratory study of mobile commerce early adopters". Journal of Organizational Computing and Electronic Commerce, Vol. 15No.2, pp. 203-222. http://dx.doi.org/10.1207/s153277 44joce 15032
[73] Quan, S., Hao, C., \&Jianxin, Y. (2010), "Factors influencing the adoption of mobile service in china: An integration of TAM". Journal of Computers, Vol. 5 No.5, pp.799-806.

[74] Roach, G. (2009), "Consumer perceptions of mobile phone marketing: a direct marketing innovation". Direct Marketing: An International Journal, Vol. 3 No. 2, pp.124-138. http://dx.doi.org/10.1108/17505930910964786

[75] Rohm, A. J., \& Sultan, F. (2006), "An exploratory cross-market study of mobile marketing acceptance. International Journal of Mobile Marketing, Vol. 1 No. 1, pp. 4-12.

[76] Samsudin, W., Kaled, A.-M., \& Nor Azila, M. N. (2010), "The relationship between e- service quality and ease of use on customer relationship management (CRM) performance: An empirical investigation in Jordan mobile phone services. Journal of Internet Banking and Commerce, Vol. 15 No. 1, pp.1-15.

[77] Schroer, W. J. 2008,"Generations X,Y, Z and the Others". The Portal : Defining, Managing, And Marketing To Generations X, Y, And $Z$.

[78] Sek, Y.-W., Lau, S.-H., Teoh, K.-K., Law, C.-Y., \&Shahril, P. (2010), "Prediction of user acceptance and adoption of smart phone for learning with technology acceptance model". Journal of applied Sciences, Vol. 10 No. 20, pp. 2395-2402. http://dx.doi.org/10.3923/jas.2010.2395.2402

[79] Shih, Y.-Y., \& Fang, K. (2004), "The use of a decomposed theory of planned behavior to study internet banking in Taiwan". Internet Research, Vol. 14 No. 3, pp. 213-223. http://dx.doi.org/10.1108/ 10662240410542643

[80] Shin, H. K., Kim, K. K., \& Lee, K. W. (2009), "Understanding the user acceptance of multimedia messaging services". Proceedings of the 11th International Conference on Advanced communication Technology, pp. 1382-1385.

[81] Solomon, Shamsuddin and Wahab (2013), "Identifying factors that determine intention to use electronic banking: A conceptual study middle-east". Journal of Scientific Research, Vol. 18No. 7, pp. 1010-1022

[82] Stone, R. N., \&Gronhaug, K. (1993), "Perceived risk: Further considerations for the marketing discipline". European Journal of Marketing, Vol. 27 No. 3, pp. 372-394. http://dx.doi.org/10.1108/ 03090569310026637

[83] Suh, B., \& Han, I. (2002), " Effect of trust on customer acceptance of Internet banking". Electronic Commerce Research and Applications, Vol. 1, pp. 247-263. http://dx.doi.org/10.1016/S15674223(02)00017-0

[84] Sultan, F., Rohm, A. J., \& Gao, T. (2009)." Factors influencing consumer acceptance of mobile marketing". Journal of Interactive Marketing, Vol. 23 No. 4, pp.308-320. http://dx.doi.org/10.1016/ j.intmar.2009.07.003

[85] Taylor, J. W. (1974). "The role of risk in consumer behavior". Journal of Marketing , Vol.38, pp.54-60. http://dx.doi.org/10.2307/1250198

[86] Taylor, S., \& Todd, P. (1995), "Decomposition and crossover effects in the theory of planned behavior: A study of consumer adoption intentions". International Journal of Research in Marketing, Vol. 12, pp. 137-155. http://dx.doi.org/10.1016/01678116(94)00019-K

[87] Torkzadeh, G., \& Dhillon, N. (2002). "Measuring factors that influence the success of Internet Commerce". Information System Research, Vol 2, pp.187-204. http://dx.doi.org/10.1287/isre. 13.2.187.87

[88] Triandis, H. C. (1980), "Values, attitudes and interpersonal behavior". In H. E. Howe, \& M. M.Page, Nebraska Symposium on Motivation 197. Lincoln, NE: University of Nebraska Press. Vol. 2, pp. 195-295

[89] Varnali, \&Toker. (2010),"Mobile marketing research: The-StateOf-The-Art".International Journal of Information Management, Vol. 30, pp. 144-151.

[90] Venkatesh, V., \& Davis, F. D. (2000), "A theoretical extension of the technology acceptance model: Four longitudinal field studies". Management Science, Vol. 46 No.2, pp. 186-204. http://dx.doi.org/10.1287/mnsc.46.2.186.11926

[91] Venkatesh, V., Morris, M. G., Davis, G. B., \& Davis, F. D. (2003), "User acceptance of information technology: toward a unified view".MIS Quarterly, Vol. 27 No.3, pp.427-478. 
[92] Wei, T. T., Marthandan, G., Chong, A. Y.-L., Ooi, K.-B., \&Arumugam, S. (2009), "What drives Malaysian m-commerce adoption? An empirical analysis".Industrial Management \& DataSystem, Vol. 109 No.3, pp. 370-388. http://dx.doi.org/10.1108/ $\underline{02635570910939399}$

[93] Wu, J.-H., \& Wang, S.-C. (2005), "What drives mobile commerce? An empirical evaluation of the revised technology acceptance model". Information \& Management, Vol. 42, pp. 719729. http://dx.doi.org/10.1016/j.im.2004.07.001

[94] Yang, Y., \& Zhang, J. (2009), "Discussion on the dimensions of consumers' perceived risk in mobile service". Eighth International Conference on Mobile Business, pp. 261-266. http://dx.doi.org/10.1109/icmb.2009.71

[95] Yun, Z., S. (2011), "Testing a theoretical model to examine the relationships among e-social shopping motivation, perception, and behavioral intention". Michigan State University.

\section{AUTHORS}

Mohammad Ismail is with Universiti Malaysia Kelan$\tan (\mathrm{UMK})$ Malaysia.He is now with the Faculty of Entrepreneurship and Business, UMK(e-mail: mohammad.i@umk.edu.my).

Razli Che Razak is with Universiti Malaysia Kelantan (UMK) Malaysia.He is now with the Faculty of Entrepre- neurship and Business, UMK (e-mail: razlicr@umk.edu.my).

Mohd Rafi Yaacob is with Universiti Malaysia Kelan$\tan (\mathrm{UMK})$, Malaysia.He is now with the Faculty of Entrepreneurship and Business, UMK(e-mail: rafi@umk.edu.my).

Mohd Nazri Zakaria is with Universiti Malaysia Kelantan (UMK), Malaysia.He is now with the Faculty of Entrepreneurship and Business, UMK (e-mail: mnazri.z@umk.edu.my).

Nadia Hanum is with Universiti Malaysia Kelantan (UMK) Malaysia.He is now with the Faculty of Entrepreneurship and Business, UMK(e-mail: nhanum@umk.edu.my).

Azyanee Luqman is a PhD Student at Faculty of Entrepreneurship and Business, Universiti Malaysia Kelan$\tan (\mathrm{UMK})$, Malaysia (e-mail: azyanee@gmail.com).

This research was conducted with a Fundamental Research Grant (FRGS) awarded by the Ministry of Higher Education Malaysia (R/FRGS/A01.00/01137A/2014/000176) entitled Predictive Modelling of Mobile Marketing usage among Gen Y: A Preliminary Survey. Submitted 03 February 2016. Published as resubmitted by the authors 26 March 2016. 